\title{
Physicochemical and microbiological quality of water from a pilot domestic rainwater harvesting facility in Ireland.
}

\author{
Sean O'Hogain \\ Technological University Dublin \\ Liam McCarton \\ Technological University Dublin, liam.mccarton@tudublin.ie \\ Niamh Mclntyre \\ City Analysis Ltd
}

See next page for additional authors

Follow this and additional works at: https://arrow.tudublin.ie/engschcivart

Part of the Environmental Engineering Commons

\section{Recommended Citation \\ O'Hogain,S, McCarton,L, Mclntyre,N, Pender,J,Reid,A; Physicochemical and microbiological quality of water from a pilot domestic rainwater harvesting facility in Ireland, Water and Environment Journal, Volume 25, Issue 4, Pages 489-494, December 2011, doi:10.1111/j.1747-6593.2010.00244.x}

This Article is brought to you for free and open access by the School of Civil and Structural Engineering at ARROW@TU Dublin. It has been accepted for inclusion in Articles by an authorized administrator of ARROW@TU

Dublin. For more information, please contact arrow.admin@tudublin.ie, aisling.coyne@tudublin.ie, gerard.connolly@tudublin.ie.

Funder: Department of the Environment, Heritage and Local Government through the National Federation of Group Water Schemes

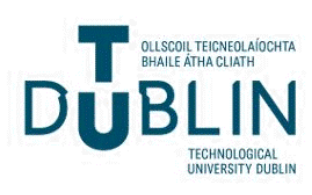




\section{Authors}

Sean O'Hogain, Liam McCarton, Niamh McIntyre, Jenny Pender, and Anna Reid 


\title{
Physicochemical and Microbiological Quality of Water from a Pilot Domestic Rainwater Harvesting Facility in Ireland.
}

\author{
Authors: \\ S. O’Hogain, PhD ${ }^{1}$, L. McCarton, BE, MSc ${ }^{2}$, N. McIntyre, BSc ${ }^{3}$, J. Pender, BSc ${ }^{4}$,A. Reid,B.Sc ${ }^{5}$. \\ School of Civil and Building Services Engineering, Dublin Institute of Technology, \\ Bolton Street, Dublin 1. \\ Ireland.
}

\begin{abstract}
DTC Research Group, Dublin Institute of Technology personnel were commissioned in 2005 by the Department of Environment, Heritage and Local Government in Ireland to assess the feasibility of utilising harvested rainwater to replace treated mains water, for non-potable uses. A pilot project was set up. The project involved the design, installation, commissioning and monitoring of rainwater harvesting facilities in a rural housing development. A monitoring program was carried out to examine the physico-chemical and microbiological quality of the harvested rainwater. Harvested rainwater was sampled monthly and tested. Analysis of the harvested rainwater quality showed a consistently high quality of raw water in general compliance with the requirements of the European Communities (Quality of Bathing Water) Regulations for $100 \%$ of samples and the European Communities (Drinking Water) Regulations, 2007 for $37 \%$ of sampling dates.
\end{abstract}

Keywords: Rainwater Harvesting, Harvested Rainwater Quality, Microbiological Analysis, Physico - Chemical Analysis, Water Standards.

\section{Introduction}

Currently municipal and group water supplies in Ireland are treated to potable standards (O'Sullivan, 2002). Public health concerns over harvested rainwater quality has limited the widespread adoption of rainwater harvesting at household level and at institutional level by Local Authorities in Ireland. This paper presents the results of a nineteen month sampling programme to establish the quality of harvested rainwater in an Irish context and to examine the potential of using rainwater harvesting systems to replace treated mains water for non-potable uses.

\section{Pilot Rainwater Harvesting Site}

The domestic site chosen was a new housing development at Ballinabrannagh, Co. Carlow. This development is located $10 \mathrm{kms}$ from Carlow town in a rural location in the South East of Ireland. Potable water is supplied to the development via a group water scheme. The housing estate consists of 48 newly built single story and two storey houses constructed in two phases. Ten houses are participating in the Rainwater Harvesting project which is being carried out on both development phases. 


\section{Rainwater Harvesting System Components}

The rainwater harvesting system collects water from roof surfaces only. Rainwater from the downpipes is diverted to an underground Rainman $1^{\mathrm{Tm}}$ filter that separates solids from the rainwater. The solids are diverted to the surface water drainage system. No first flush or diversion device is installed. The harvested rainwater water is diverted to a $9 \mathrm{~m}^{3}$ underground precast concrete collection tank. All connections to the rainwater drainage system are sealed to prevent contamination from surface water. Harvested rainwater is pumped into the dwelling to a separate rainwater header tank located in the attic. The rainwater is then delivered by gravity to provide water for toilet flushing and external garden taps. In periods of low rainfall the rainwater header tank is filled from the mains water header tank by means of a solenoid valve. A tundish type AA air gap is installed to ensure that no backflow to the mains water supply can occur. A data logger system is also installed with flow monitoring to assess micro component household water usage. A weather station is installed on site to generate water balance data (O’Hogain, 2006).

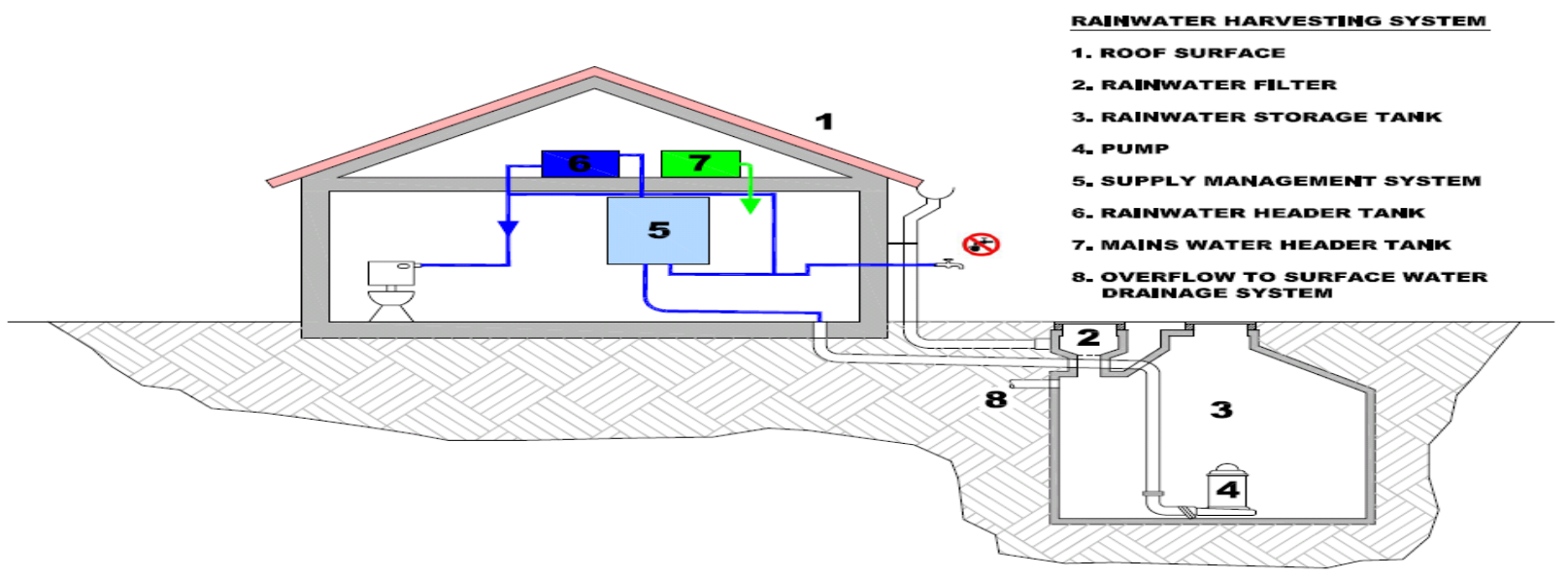

Fig 1 Schematic of Pilot Rainwater Harvesting Installation, Co. Carlow

\section{Results}

\section{Sampling}

Rainwater from the underground reservoir was sampled monthly for nineteen months between January 2006 and July 2007. Samples were taken aseptically and transported to the laboratory within 4 hours and were stored between $2-8^{\circ} \mathrm{C}$ in accordance with ISO / IEC 17025:2005 (ISO 17025, 2005). The physico-chemical analysis tested for Chloride, Nitrate, Nitrite, Sulphate, Ammonia, pH, Total Dissolved Solids (TDS), Total Suspended Solids (TSS), Turbidity, Sodium, Calcium, Lead, Iron and Cadmium. Samples for microbiological analysis were taken in sterile bottles to ensure no crosscontamination. They were analysed for the time dependent parameters Coliforms, E. coli, Faecal coliforms, Total Viable Counts (TVC) at $22^{\circ} \mathrm{C}$ and $37^{\circ} \mathrm{C}$ and Pseudomonas spp. within1 hour of receipt in the laboratory. All analysis of water quality parameters was carried in an Irish National Accreditation Body (INAB) accredited laboratory as per Standard Methods (Standard Methods, 2005). In order for water to be considered fully potable it must undergo testing for 28 different parameters set 
out in the full audit monitoring list of the European Communities (Drinking Water) (No. 2) Regulations, S.I. No. 278 of 2007. However, the majority of these pollutants only arise in water treatment processes or when water is flowing through rock and soil. Although it was not necessary to monitor for all of these parameters, one full audit suite of testing was carried out and the results proved to be within guidelines specified in the regulations (European Communities, S.I. No. 278, 2007).

\section{Physicochemical Water Quality}

The physicochemical results for the domestic site are shown in Table 1 . There are currently no specific national guidelines applying to the use of rainwater for domestic supply. Results for the harvested rainwater quality are compared with the European Communities (Drinking Water) (No. 2) Regulations, S.I. No. 278 of 2007 and the European Communities (Quality of Bathing Water) Regulations, S.I. 155 of 1992 (henceforth referred to as Drinking Water Regulations and Bathing Water Regulations respectively). It was considered an important function of the project to collect data on raw harvested rainwater. For this reason no disinfection programme was carried out at any stage in the rainwater harvesting process and no first flush device was fitted to the system.

There are no limits for Sulphate and Nitrate parameters in the Bathing Water Regulations but the results for these parameters are significantly lower than the limits set down in the Drinking Water Regulations. Nitrite is slightly below the limit of $0.50 \mathrm{mg} / \mathrm{l}$ in drinking water with a maximum of 0.49 $\mathrm{mg} / \mathrm{l}$. Ammonia as $\mathrm{NH}_{3}$ demonstrated a mean of $0.12 \mathrm{mg} / \mathrm{l}$ with a minimum of 0 and a maximum of $0.77 \mathrm{mg} / \mathrm{l}$. These results are below the limits for both drinking and bathing water. Total Dissolved Solids (TDS) showed a mean value of $84.63 \mathrm{mg} / \mathrm{l}$, with a minimum of 6.00 and a maximum of 189 $\mathrm{mg} / \mathrm{l}$ while Total Suspended Solids (TSS) showed a mean of $5.37 \mathrm{mg} / \mathrm{l}$ with a minimum of 0 and a maximum of $25 \mathrm{mg} / \mathrm{l}$. Neither of these parameters is cited in the Drinking Water or Bathing Water directives. Turbidity gave a mean result of 1.10 NTU with a minimum of 0 and a maximum of 4.60 NTU. The Drinking Water legislation requires that the turbidity of the water shows no abnormal change and is acceptable to consumers.

Metals results were all within the limits set out in the Drinking Water Regulations with the exception of lead, where a maximum of $25.32 \mathrm{mg} / \mathrm{l}$ was recorded in one sample. There is no legislation governing the concentration of Calcium in either Drinking or Bathing Water Regulations. The Iron results showed a mean of $25.66 \mu \mathrm{g} / \mathrm{l}$ with a minimum of 0 and a maximum of $95 \mu \mathrm{g} / \mathrm{l}$. This is below the $200 \mu \mathrm{g} / 1$ maximum allowed in drinking water. Total Cadmium demonstrated a mean of $0.03 \mu \mathrm{g} / \mathrm{l}$ with a minimum of 0 and a maximum of $0.30 \mu \mathrm{g} / \mathrm{l}$. Cadmium is not cited in the Bathing Water Regulations and the parametric value specified for Drinking Water is $5.0 \mu \mathrm{g} / \mathrm{l}$. Of all the physicochemical parameters tested only two were in breach of Drinking Water Regulations, Lead with a maximum of $25.32 \mu \mathrm{g} / \mathrm{l}$ and $\mathrm{pH}$ where a minimum of 6.26 was recorded in one sample. All parameters complied with the requirements of the Bathing Water Regulations. 


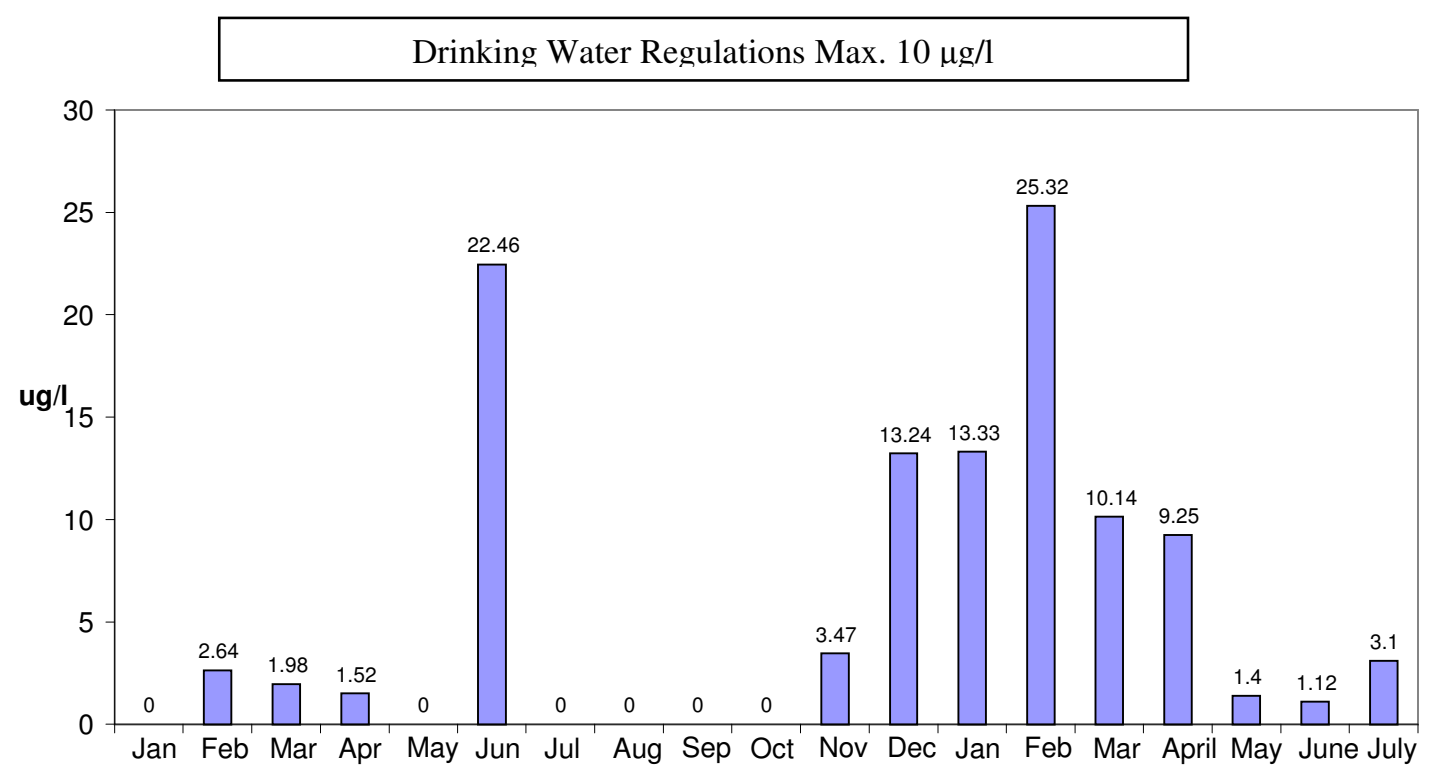

Sampling Period: Jan 2006 to July 2007

Fig. 2 Harvested Rainwater Quality Results for Lead from Jan 2006 to July 2007.

\section{Microbiological Water Quality}

Table 2 presents the microbiological monitoring results for the domestic site over the 19 months of sampling between January 2006 and July 2007.

Coliforms had a maximum of $1203.3 \mathrm{MPN} / 100 \mathrm{ml}$, a minimum of 0.00 and a mean of 216.83 MPN/100ml. There should not be any coliforms detected in a drinking water sample according to European Drinking Water Regulations. Therefore, both the mean and maximum results are in breach of these regulations. However, the maximum concentration allowed in a Bathing Water sample is 5000 MPN/100ml meaning that the results are within the limits with reference to the Bathing Water regulations.

The maximum result for $E$. coli was $7.50 \mathrm{MPN} / 100 \mathrm{ml}$, the minimum was 0.00 and the mean was 0.39 MPN/100ml. The Drinking Water Regulations require that the water be free from E. coli, with the bathing water regulations specifying an allowable limit of $1000 \mathrm{MPN} / 100 \mathrm{ml}$. Faecal coliforms were also detected with a maximum of 22.00 , a minimum of 0 and a mean of 3 . TVC at $22^{\circ} \mathrm{C}$ showed a maximum of 35400 , a minimum of 1.00 and a mean $3264.11 \mathrm{cfu} / \mathrm{ml}$ and $\mathrm{TVC}$ at $37^{\circ} \mathrm{C}$ had maximum of 704, a minimum of 3.00 and a mean of $216.26 \mathrm{cfu} / \mathrm{ml}$. Pseudomonas spp had maximum result of 80 $\mathrm{cfu} / 100 \mathrm{ml}$, a minimum of 0.00 and a mean of $6.00 \mathrm{cfu} / 100 \mathrm{ml}$.

Table 3 presents a summary of the microbiological results after the first six months of operation which shows that a pronounced improvement in harvested rainwater quality occurs after the first six months. No coliforms, E. coli or faecal coliforms were detected in any of these samples. The TVCs at $22^{\circ} \mathrm{C}$ had a maximum result of $3000 \mathrm{cfu} / \mathrm{ml}$, a minimum of 1.00 and a mean $975.00 \mathrm{cfu} / \mathrm{ml}$. TVCs at $37^{\circ} \mathrm{C}$ reached a maximum result of $704 \mathrm{cfu} / \mathrm{ml}$, a minimum of 3.00 and a mean of $241.71 \mathrm{cfu} / \mathrm{ml}$. Pseudomonas spp showed a maximum result of $80 \mathrm{cfu} / 100 \mathrm{ml}$, a minimum of 0 and a mean 7.92 $\mathrm{cfu} / 100 \mathrm{ml}$. 


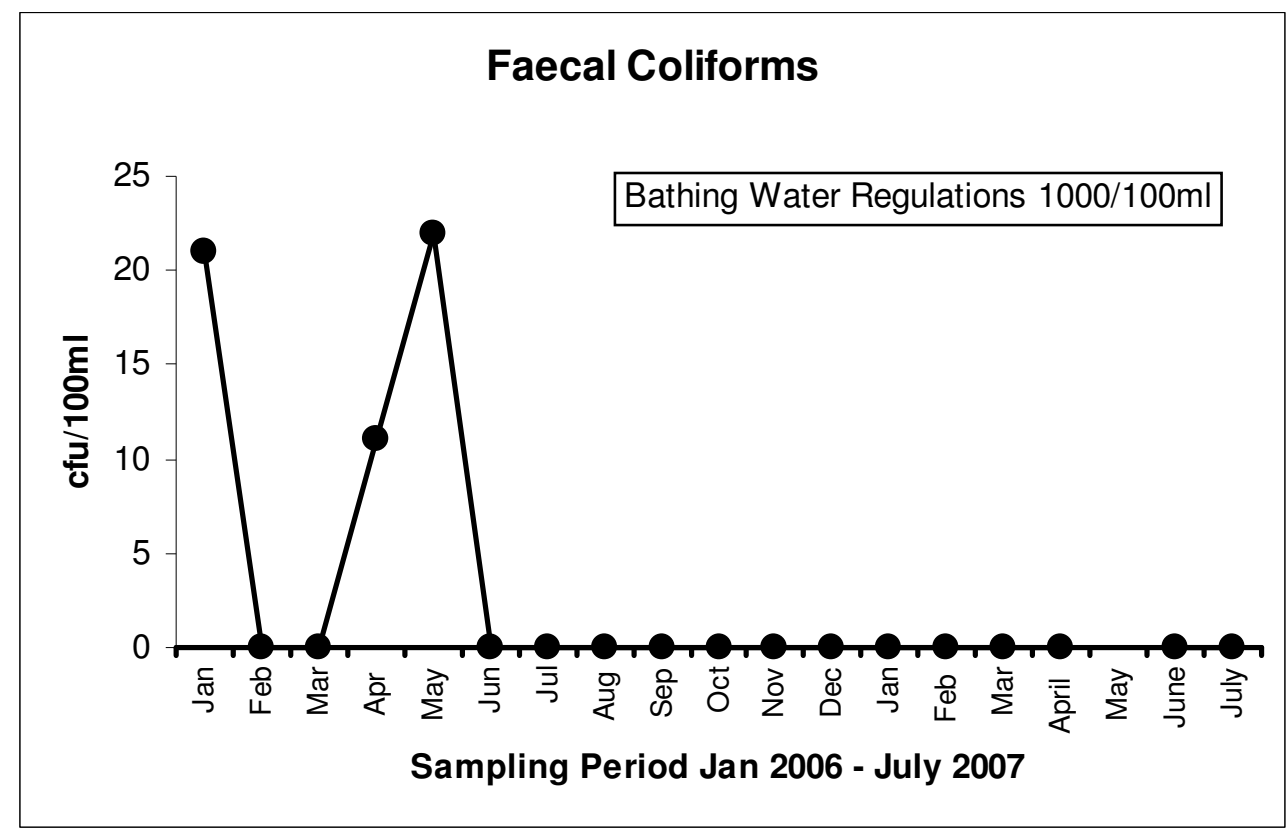

Fig 3 Faecal Coliform results for Harvested Rainwater January 2006 - July 2007.

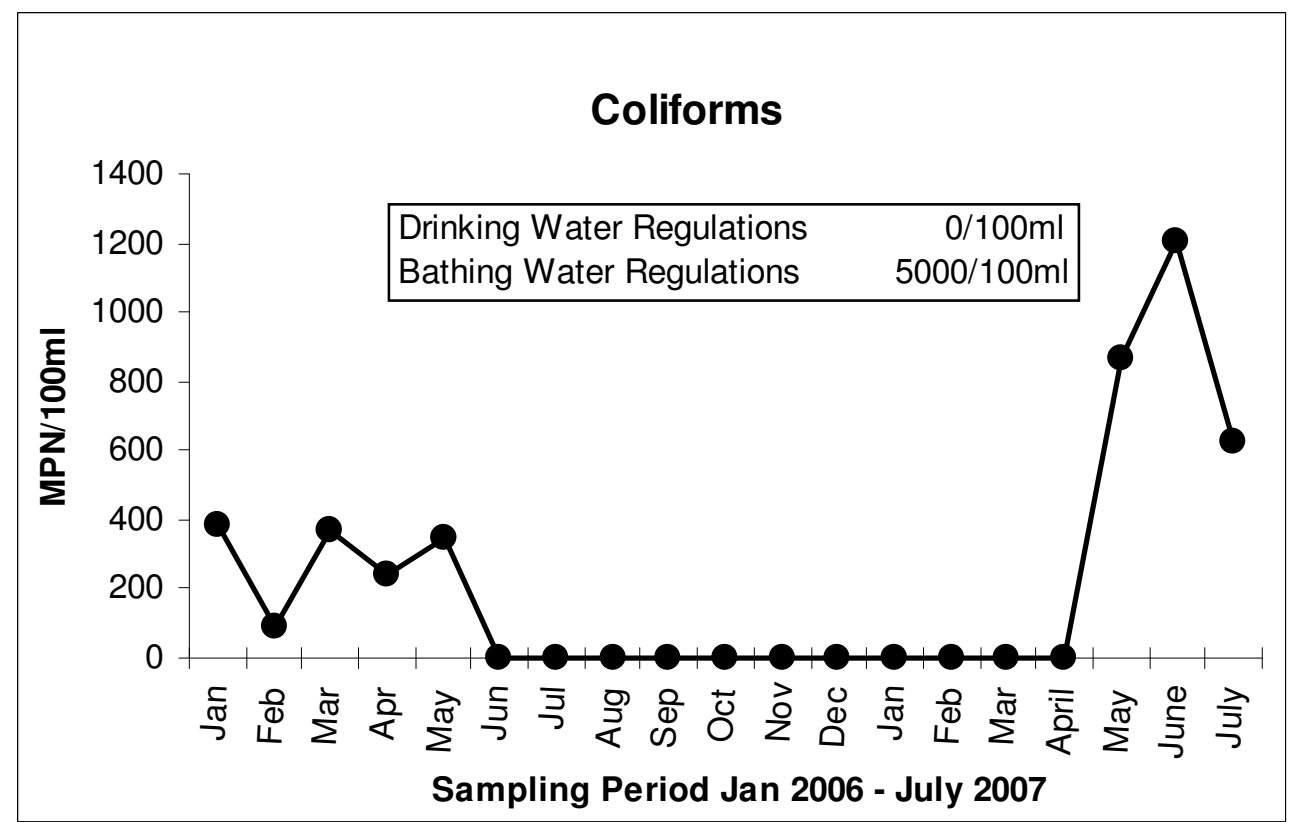

Fig 4 Coliform Results for Harvested Rainwater January 2006 - July 2007. 


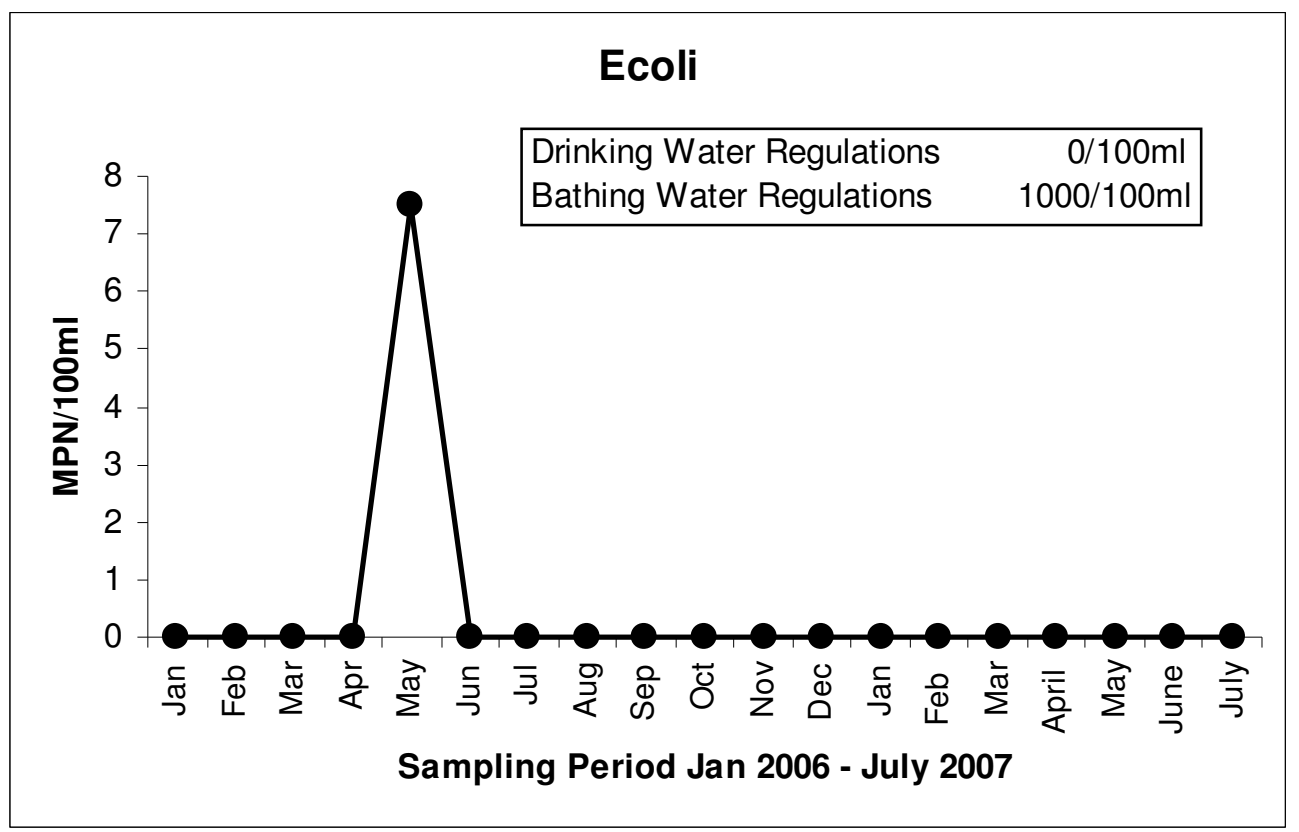

Fig 5 E.coli Results for Harvested Rainwater January 2006 - July 2007.

\author{
Discussion of Results
}

\title{
Chemical Quality
}

The physicochemical quality of harvested rainwater in Carlow was of very good quality. The rainwater complied with the Bathing Water Regulations at all times. Compliance with the more stringent Drinking Water Regulations was achieved for all parameters except $\mathrm{pH}$ and Lead. The $\mathrm{pH}$ results had a mean of $7.24 \mathrm{pH}$ units with a minimum of 6.26 and a maximum of 8.21. The lower limit in the European Drinking Water Regulations is 6.5 and samples were slightly below this on three occasions with the lowest value being 6.26 in May 2006. The $\mathrm{pH}$ was always within the allowable range for bathing water.

Fig 2 illustrates the results for Lead, which had a mean concentration of $5.74 \mu \mathrm{g} / \mathrm{l}$ with a minimum of 0 and a maximum of $25.32 \mu \mathrm{g} / \mathrm{l}$. The Drinking Water Regulations impose a parametric value of $25 \mu \mathrm{g} / \mathrm{l}$ $\mathrm{Pb}$ until the $25^{\text {th }}$ December 2013 after which the parametric value of $10 \mu \mathrm{g} / \mathrm{l} \mathrm{Pb}$ becomes effective (EPA, 2006). The harvested rainwater was in breach of the $10 \mathrm{ug} / 1$ limit on 5 occasions with the highest level being over twice the maximum allowed at $25.32 \mathrm{mg} / \mathrm{l}$. This represented a $73.6 \%$ compliance rate. Construction of phase two of the development was ongoing during the sampling period. This could have contributed to the presence of lead in the rainwater. However, a more likely contribution to the lead in the rainwater is the flashings used on the rainwater harvesting house. The soft nature of the rainwater may have leached some lead from these flashings. Rainwater harvesting manuals recommend using an alternative metal than lead for flashings, where rainwater is to be used for purposes that involve contact with humans (Texas Guide, 1997). 


\section{Microbiological Quality}

In general terms, the greatest microbial risks are associated with ingestion of water that is contaminated with human or animal (including bird) faeces. Faeces can be a source of pathogenic bacteria, viruses, protozoa and helminths. Faecally derived pathogens are the principal concerns in setting health-based targets for microbial safety (WHO, 2006). The microbiological results show compliance with EU Bathing Water Regulations at all times. Compliance with the more stringent Drinking Water Regulations was achieved for ten out of nineteen sampling dates. Three distinct trends show up within the results (figures 4, 5 and 6). The initial period of sampling from January 2006 until June 2007 showed levels of faecal indicator organisms (coliforms, E. coli and faecal coliforms) present, in breach of Drinking Water Regulations. Coliforms were detected in each sample taken from January 2006 to May 2006 with E. coli present on one occasion and faecal coliforms present on three sampling dates.

Coliforms are classed as faecal indicator organisms but can be caused by the presence of rotting vegetation, while bird droppings washed down from the roof could account for $E$. coli and faecal coliforms. During construction of the house and installation of the rainwater harvesting system the collection tank was left open for long periods of time. This would have allowed for significant contamination to occur. Building work in the vicinity of the site continued for the duration of the sampling period further increasing the potential for contamination.

A second trend appears from July 2006 to April 2007. During this period the harvested rainwater was in compliance with Drinking Water regulations. This water was suitable for use as potable water during these 11 months.

A further trend appears in the last three sampling dates, where the water quality shows breaches of drinking water regulations in the Coliform parameter only. As it was only coliforms that were detected and not E.coli, this indicates that the probable source of contamination was rotting vegetation. Leaves, twigs etc. may have built up in the gutters and a few days of heavy rain could have washed some of this into the collection tank. If harvested rainwater is to be used for human consumption regular and scheduled maintenance of the system should be carried out. This should include cleaning out the gutters and periodic checking and cleaning of the filter. A first flush device could also be installed to eliminate any contamination that has collected during dry periods without rain.

There are no limits for TVCs (Total Viable Counts) in Bathing Water Regulations and Drinking Water Regulations require that there are no abnormal changes in numbers detected when monitoring systems over a period of time. A sudden increase in the numbers of microorganisms counted can mean that a pollution incident has occurred to upset the normal microbiological balance of the system. The results show TVC counts from the rainwater harvesting system were extremely variable. This indicates that the system is not microbiologically stable. No chlorination of harvested rainwater was carried out at any stage during the project, and as a result there was no residual chlorine present to keep the water microbiologically stable.

\section{Conclusions}

1. The rainwater harvested at the domestic installation in County Carlow was in compliance with the Bathing Water Regulations for $100 \%$ of samples taken and was of a suitable quality for use in non potable applications.

2. Results showed that for the harvested rainwater complied with the more stringent Drinking Water Regulations for $37 \%$ of samples taken. 
3. These monitoring results represent a worst case scenario, as no first flush device was installed and no disinfection of the system took place.

4. An efficient disinfection programme would have ensured that the quality of the harvested rainwater was in compliance with Microbiological Drinking Water Regulations.

5. Lead flashings should not be used on any rainwater harvesting facility where water is to be used for potable applications.

6. Regular maintenance of the system is advised to ensure optimum water quality.

\section{Acknowledgements}

The Authors gratefully acknowledge the assistance provided by the National Federation of Group Water Schemes, the Department of Civil \& Structural Engineering, Dublin Institute of Technology, Carlow County Council and City Analysts. Funding for the study was provided by the Department of Environment, Heritage \& Local Government through the National Rural Water Monitoring Committee.

\section{References}

Environmental Protection Agency, 2005. The Quality of Drinking Water in Ireland. A Report for the Year 2005, Environmental Protection Agency, 2006, ISBN 1-84095-213X

European Communities, (Drinking Water) Regulations, 2007. S.I. No. 106 of 2007.

European Communities, (Drinking Water) (No. 2) Regulations, 2007. S.I. No. 278 of 2007.

European Communities, (Quality Of Bathing Waters) Regulations, 1992. S.I. No. 155 of 1992.

ISO/IEC, 17025 International Standard General requirements for the competence of testing and calibration laboratories, ISO/IEC 2005.

Met Eireann, Climate of Ireland, [online], Met Eireann, Available from :http://www.met.ie/climate/climate-of-ireland.asp, [accessed on 15 May 2006]

O'Hogain, S., Reid, A., McIntyre, N. , Pender, J., McCarton, L,. (2007). "Water Savings \& Rainwater Harvesting - A Pilot Project in Ireland". Aqua Enviro European Water \& Wastewater Conference, ISBN 1-903958-24-5

O'Sullivan, G. (2002). Water Supply - The Supply/Demand Problem. Institution of Engineers of Ireland, 22 Clyde Rd., Ballsbridge, Dublin4, Ireland.

Standard Methods for the Examination of Water and Wastewater (2005). 21st edn,. American Public Health Association/American Water Works Association/Water Environment Federation, Washington DC, USA.

World Health Organization. Guidelines for drinking-water quality [electronic resource] http://www.who.int/water_sanitation_health/dwq/gdwq3rev/en/index.html: incorporating first addendum. Vol. 1, Recommendations. - 3rd ed. [accessed on 21 August 2006].

Texas Guide to Rainwater Harvesting, Texas Water Development Board in Cooperation with Centre for Maximum Potential Building Systems, Second Edition 1997. Available from http://www.metaefficient.com/pdf/RainHarv.pdf [accessed on 24 May 2006].

\section{Word Count}

Total Word Count $=3,318$ 
Table 1. Overall Physico-chemical results for the harvested rainwater based on 19 monthly samples taken between January 2006 and July 2007 .

\begin{tabular}{|c|c|c|c|c|c|c|c|c|}
\hline Parameters & Units & Mean & Min & Max & SD & Median & $\begin{array}{c}\text { Drinking } \\
\text { Water } \\
\text { Regulations }\end{array}$ & $\begin{array}{c}\text { Bathing } \\
\text { Water } \\
\text { Regulations }\end{array}$ \\
\hline Chloride & $\mathrm{mg} / \mathrm{l}$ & 5.73 & 1.50 & 22.49 & 4.86 & 5.06 & $250 \mathrm{mg} / \mathrm{l}$ & \\
\hline Nitrate as $\mathrm{NO}_{3}$ & $\mathrm{mg} / \mathrm{l}$ & 1.14 & 0.00 & 2.84 & 0.97 & 1.24 & $50 \mathrm{mg} / \mathrm{l}$ & \\
\hline Nitrite as $\mathrm{NO}_{2}$ & $\mathrm{mg} / \mathrm{l}$ & 0.06 & 0.00 & 0.49 & 0.11 & 0.03 & $0.50 \mathrm{mg} / \mathrm{l}$ & \\
\hline Sulphate & $\mathrm{mg} / \mathrm{l}$ & 8.66 & 0.00 & 31.70 & 9.32 & 7.50 & $250 \mathrm{mg} / \mathrm{l}$ & \\
\hline Ammonia $\mathrm{NH}_{3}$ & $\mathrm{mg} / \mathrm{l}$ & 0.12 & 0.00 & 0.77 & 0.20 & 0.05 & $0.28 \mathrm{mg} / \mathrm{l}$ & \\
\hline $\mathrm{pH}$ & $\mathrm{pH}$ Units & 7.24 & 6.26 & 8.21 & 0.55 & 7.21 & $6.5-9.5$ & $6.0-9.0$ \\
\hline TDS & $\mathrm{mg} / \mathrm{l}$ & 84.63 & 6.00 & 189.00 & 39.43 & 77.00 & & \\
\hline TSS & $\mathrm{mg} / \mathrm{l}$ & 5.37 & 0.00 & 25.00 & 5.78 & 4.00 & & \\
\hline Turbidity & NTU & 1.10 & 0.00 & 4.60 & 1.21 & 1.11 & NAC\&ATC* & \\
\hline Sodium & $\mathrm{mg} / \mathrm{l}$ & 4.15 & 0.00 & 8.60 & 3.13 & 4.60 & $200 \mathrm{mg} / \mathrm{l}$ & \\
\hline Calcium & $\mathrm{mg} / \mathrm{l}$ & 13.32 & 3.10 & 23.20 & 5.35 & 14.00 & None & \\
\hline Lead,Total & $\mu \mathrm{g} / \mathrm{l}$ & 5.74 & 0.00 & 25.32 & 7.82 & 1.98 & $10 \mu \mathrm{g} / \mathrm{l}$ ** & \\
\hline Iron,Total & $\mu \mathrm{g} / \mathrm{l}$ & 25.66 & 0.00 & 95.03 & 25.25 & 21.73 & $200 \mu \mathrm{g} / \mathrm{l}$ & \\
\hline $\begin{array}{l}\text { Cadmium,Total } \\
* \quad \text { No abnormal } \\
{ }^{*} \text { The Regulati } \\
\text { value of } 10 \mu \mathrm{g} / \mathrm{l}\end{array}$ & $\begin{array}{c}\mu \mathrm{g} / \mathrm{l} \\
\text { ange and } \\
\text { impose } \\
\text { comes eff }\end{array}$ & $\begin{array}{l}0.03 \\
\text { ceptabl } \\
\text { parame } \\
\text { tive }\end{array}$ & $\begin{array}{c}0.00 \\
\text { consu }\end{array}$ & 0.30 & 0.08 & 0.00 & $5.0 \mu \mathrm{g} / \mathrm{l}$ & e parametric \\
\hline
\end{tabular}

Table 2. Overall microbiological results for the harvested rainwater based on 19 monthly samples taken between January 2006 and July 2007.

\begin{tabular}{|c|c|c|c|c|c|c|c|c|}
\hline Parameters & Units & Mean & Min & Max & SD & Median & $\begin{array}{l}\text { Drinking } \\
\text { water } \\
\text { Regulations }\end{array}$ & $\begin{array}{l}\text { Bathing } \\
\text { Water } \\
\text { Regulations }\end{array}$ \\
\hline Coliforms & MPN/100ml & 216.83 & 0.00 & 1203.30 & 346.56 & 365.4 & $0 \mathrm{no} . / 100 \mathrm{ml}$ & $5000 / 100 \mathrm{ml}$ \\
\hline E. coli & MPN/100ml & 0.39 & 0.00 & 7.50 & 1.72 & 3.75 & 0 no. $/ 100 \mathrm{ml}$ & $1000 / 100 \mathrm{ml}$ \\
\hline $\begin{array}{l}\text { Faecal } \\
\text { Coliforms }\end{array}$ & CFU/100ml & 3.00 & 0.00 & 22.00 & 7.21 & 0.00 & & $1000 / 100 \mathrm{ml}$ \\
\hline TVC @ 22ㄷ & $\mathrm{Cfu} / \mathrm{ml}$ & 3264.11 & 1.00 & 35400.00 & 8178.81 & 546.50 & NAC $^{*}$ & \\
\hline TVC @ $37^{\circ} \mathrm{C}$ & $\mathrm{Cfu} / \mathrm{ml}$ & 216.26 & 3.00 & 704.00 & 215.08 & 169.00 & NAC* & \\
\hline $\begin{array}{l}\text { Pseudomonas } \\
\text { spp } \\
{ }^{*} \text { No abnormal c }\end{array}$ & cfu/100ml & 6.00 & 0.00 & 80.00 & 19.43 & 15.00 & & \\
\hline
\end{tabular}


Table 3. Microbiological results for the harvested rainwater based on monthly samples taken between June 2006 and April 2007, after first six months commissioning stage i.e. the period of sampling where no faecal indicator organisms were present.

\begin{tabular}{|c|c|c|c|c|c|c|c|c|}
\hline Parameters & Units & Mean & Min & Max & SD & Median & $\begin{array}{c}\text { Drinking } \\
\text { water } \\
\text { Regulations }\end{array}$ & $\begin{array}{c}\text { Bathing } \\
\text { Water } \\
\text { Regulations }\end{array}$ \\
\hline Coliforms & MPN/100ml & 0.00 & 0.00 & 0.00 & 0.00 & 0.00 & 0 no. $/ 100 \mathrm{ml}$ & $5000 / 100 \mathrm{ml}$ \\
\hline E. coli & MPN/100ml & 0.00 & 0.00 & 0.00 & 0.00 & 0.00 & 0 no. $/ 100 \mathrm{ml}$ & $1000 / 100 \mathrm{ml}$ \\
\hline Faecal Coliforms & $\mathrm{cfu} / 100 \mathrm{ml}$ & 0.00 & 0.00 & 0.00 & 0.00 & 0.00 & & $1000 / 100 \mathrm{ml}$ \\
\hline TVC @ 22ㄷ & $\mathrm{Cfu} / \mathrm{ml}$ & 975.00 & 1.00 & 3000.00 & 1234.98 & 300.00 & NAC* & \\
\hline $\begin{array}{l}\text { TVC @ } 37^{\circ} \mathrm{O} C \\
\text { Pseudomonas } \\
\text { spp }\end{array}$ & $\begin{array}{l}\text { Cfu/ml } \\
\mathrm{cfu} / 100 \mathrm{ml}\end{array}$ & $\begin{array}{c}241.71 \\
7.92\end{array}$ & $\begin{array}{l}3.00 \\
0.00\end{array}$ & $\begin{array}{l}704.00 \\
80.00\end{array}$ & $\begin{array}{l}243.34 \\
23.11\end{array}$ & $\begin{array}{c}183.50 \\
0.00\end{array}$ & NAC $^{*}$ & \\
\hline
\end{tabular}

